\title{
A systematic review of the clinical and social epidemiological research among sex workers in Uganda
}

Katherine A. Muldoon ${ }^{1,2}$

\begin{abstract}
Background: In response to the high burden of disease among sex workers and their position as a population heavily affected by the HIV epidemic, there has been a growing body of literature investigating the prevalence and risk factors associated with HIV risk among sex workers. To contextualize and summarize the existing research evidence base, a systematic review was conducted to synthesize the epidemiological literature on sex workers in Uganda.

Methods: Database selection and search strategy development followed the Cochrane Collaboration's standards for conducting systematic review searches. All studies that included sex workers as the primary research participants were included in the review. The search was then geographically restricted to the country of Uganda. Items were identified from 18 databases (grey and peer-review) on March 10-11, 2015.

Results: A total of 484 articles were retrieved from the database search. After removal of duplicates, a total of 353 articles were screened for eligibility and 64 full-text articles were assessed. The final review included 24 studies with quantitative methodology conducted among sex workers in Uganda. The HIV prevalence among female sex workers ranged from 32.4-52.0 \% and between 8.2-9.0\% had multiple HIV infections. Both multi-drug resistance to antiretroviral therapy (2.6\%) and antibiotics (83.1\%) were observed. Between 33.3-55.1\% reported inconsistent condom use in the past month. In the previous 6 months, over $80 \%$ of sex workers experienced client-perpetrated violence and $18 \%$ experienced intimate partner violence. Over $30 \%$ had a history of extreme war-related trauma.

Conclusions: There was limited information on socio-structural factors that affect sex workers' commercial working environments in Uganda, including the role of policing and criminalization, as well as the prevalence and factors associated with violence. The majority of the existing evidence is based in Kampala, highlighting a need for information on sex work in other regions of Uganda. Additionally, there is limited information on features of the non-commercial components of sex workers' lives as well as the services needed to reduce risks outside of the sex industry.
\end{abstract}

Keywords: Sex work, Structural determinants, HIV/AIDS, Violence, Uganda

\footnotetext{
Correspondence: Katherine.muldoon@gmail.com

${ }^{1}$ School of Population and Public Health, Faculty of Medicine, University of British Columbia, 2206 East Mall, Vancouver, BC V6T 1Z9, Canada

${ }^{2}$ Ottawa Hospital Research Institute, University of Ottawa, 501 Smyth Road, Ottawa, ON K1H 8L6, Canada
}

\section{Biomed Central}

(c) 2015 Muldoon. Open Access This article is distributed under the terms of the Creative Commons Attribution 4.0 International License (http://creativecommons.org/licenses/by/4.0/2, which permits unrestricted use, distribution, and reproduction in any medium, provided you give appropriate credit to the original author(s) and the source, provide a link to the Creative Commons license, and indicate if changes were made. The Creative Commons Public Domain Dedication waiver (http://creativecommons.org/publicdomain/zero/1.0/) applies to the data made available in this article, unless otherwise stated. 


\section{Background}

The high prevalence of HIV among sex workers has been consistently documented from the beginning of the HIV epidemic [1]. Studies from the early 1980s began to document the high prevalence of HIV among sex workers within Uganda [2-4]. The Ugandan Government was quick to acknowledge the scale and severity of the HIV epidemic within the general population and began large scale campaigns to encourage condom use and reduce the number of sexual partners [5]. As a result, there is a large body of clinical research on HIV in Uganda, including many clinical trials, particularly among serodiscordant couples [6] and on the prevention of mother to child transmission [7], but much less research among key affected populations such as sex workers [8]. Countrywide prevalence estimates, based on available data, suggest that approximately one-third or $37.2 \%$ (95 \% CI: $34.2 \%-$ $40.2 \%$ ) of female sex workers are living with HIV in Uganda compared to $8.5 \%$ among the general Ugandan female population of reproductive age [1]. The sustained levels of HIV suggest that there are larger structural barriers to health care and social and environmental factors that constrain sex workers' choices and ability to reduce risk and exposure to HIV [9-11].

In response to the high burden of disease among sex workers and their position as a population heavily affected by the HIV epidemic, there has been a growing body of literature investigating the prevalence and risk factors associated with HIV risk among sex workers. In addition to the high burden of HIV/STIs among sex workers across sub-Saharan Africa [1, 11-14], there has also been a focus on the factors that influence sex workers' ability to protect themselves, their clients, intimate partners, and families from risk [10]. Sex workers often have limited economic options and provide for many dependent children and family members, with limited access to education [11, 15-17].

In many countries in sub-Saharan Africa, sex work is criminalized and sex workers are often persecuted with little protection available from police or social services. In the Ugandan Penal Code, all aspects of sex work are considered illegal including the sale of sex, solicitation, communications for the purposes of sales, and third party entities such as clients, brothel owners, pimps/ managers or those otherwise living off the earnings of prostitution [18]. Additionally, in 2014, the government of Uganda enacted the Anti-Pornography Act [19], previously known colloquially as the "Miniskirt Bill" [20]. In its original Bill form, pornography was described as a criminal offence and defined as "a) a person engaged in explicit sexual activities or conduct; b) exposing sexual parts of a person such as breasts, thighs, buttocks or genitalia; c) erotic behavior intended to cause sexual excitement; or d) any indecent act or behavior tending to corrupt morals." The broad scope of the Bill was problematic and refined. When the Bill was enacted pornography was defined as “...any representation through publication, exhibition, cinematography, indecent show, information technology or by whatever means, of a person engaged in real or simulated explicit sexual activities or any representation of the sexual parts of a person for primarily sexual excitement". The Anti-Pornography Act does not specifically use the terms prostitution or sex work; however, it further criminalizes the sex industry and provides sufficient legal infrastructure to arrest, detain, and harass sex workers.

Despite the development of the Anti-Pornography Act, the Ugandan government has made a commitment to improve access to HIV care and treatment for sex workers in the Ugandan National HIV Strategic Plan [21]. Qualitative research among sex workers in Uganda has shown that the criminalized status of sex work excuses extreme violence against sex workers, inhibits their ability to reduce HIV risk and negotiate condom use, and often displaces them to isolated and dangerous areas to avoid police harassment [22-25]. Despite the ongoing documentation of the increased HIV risk, to date there has been no acknowledgement from the Ugandan government that criminalizing sex work could undermine HIV prevention efforts.

Many studies have documented the extreme human rights abuses that sex workers face including homicide, physical and sexual violence, unlawful arrest or detention, and discrimination when accessing health services $[14,16,26]$. Sex workers will often forgo condom use because of fear of violence from clients, police or pimps/managers $[10,15,16,27]$. Although there is limited epidemiological research, there is a growing body of qualitative research among Ugandan sex workers describing the common occurrence of violence from clients, including extreme acts of gang rape and physical assault $[22,23,28-30]$. Studies have documented that police can be both perpetrators and enablers of violence against sex workers [30]. To date, there is limited quantitative evidence on the burden of violence against sex workers in Uganda, an important and neglected area for investigation.

Reviews of the literature among sex workers in subSaharan Africa have documented a high unmet need for comprehensive health care services that include HIV treatment, prevention and care, sexual reproductive health, harm reduction, and psychosocial support $[10,31,32]$. Ensuring equitable and non-judgmental access to HIV care for sex workers in sub-Saharan Africa is a priority identified by sex work advocacy and community groups [24, 33] and endorsed by global governing bodies [34-36]. Even with examples of successful service provision, many remain small in 
scope and precariously funded, and few are able to address the structural drivers of risk including discrimination, violence, and lack of protections through criminalized law. Qualitative studies among sex workers in Uganda have cited discrimination from health care providers and difficulty accessing condoms as key barriers to care [24, 29]. Engaging sex workers in the continuum of HIV care is a necessary component of HIV prevention and treatment. Consequently, many sex workers may not know their HIV status, lack access to testing and treatment, and face stigma and discrimination from health care providers that inhibit retention in care $[37,38]$. Specialized programming and effective interventions to increase condom use, access to HIV/STI testing and treatment, and access to primary and comprehensive care for sex workers are needed [39].

In response to the recognition of heightened risk of HIV/STI infection and transmission among sex workers, several studies have been conducted in Uganda. Uganda is an interesting case study where sex work is increasingly criminalized and yet sex workers are also acknowledged as a priority population for HIV prevention, treatment and care in national and global guidelines. Information on sex workers in Uganda spans national survey data, clinical trials and social analyses of sex worker health and safety. This systematic review was designed to be broad in scope and geographically restricted to Uganda to provide a country-level synthesis of sex workers across multiple disciplines. Results focus on the prevalence of HIV/STIs and factors that influence risk.

\section{Methods}

\section{Search strategy}

Prospero, the prospective registration platform for systematic reviews was searched on March 8, 2015 to determine if there was an existing systematic review registered or published on topics related to sex workers in Uganda [40]. None was found. A more sensitive search strategy was designed to retrieve studies from other electronic bibliographic databases. Database selection and search strategy development followed the Cochrane Collaboration's current international Methodological standards for the conduct of new Cochrane Intervention Reviews (MECIR) standards for conducting systematic review searches [41]. Items were identified from the following databases on March 10-11, 2015: Cochrane Library via Wiley (Issue 3 of 12, 2015); Campbell Collaboration Library of Reviews; MEDLINE and PreMEDLINE via OVID (1946-present); PSYCINFO via OVID (1861-present); Sociological Abstracts via Proquest (1952-present); Dissertations and Theses via Proquest (1743-present); EconLit via Proquest (1982-present); IDEAS Economics and Finance Research via web (all years); British Library for Development
Studies (BLDS) via web (all years); ISI-Web of Knowledge via Thompson; Web of Science Core Collection: Citation Indexes; Science Citation Index Expanded (SCI-EXPANDED) (1900-present); Social Sciences Citation Index (SSCI) -1900-present; Arts \& Humanities Citation Index (A\&HCI) -1975-present; Conference Proceedings Citation Index- Science (CPCI-S) -1990-present; Conference Proceedings Citation Index- Social Science \& Humanities (CPCI-SSH) -1990-present; Health Evidence (database of public health systematic reviews) (all years); CAB Direct (CAB Abstracts \& Global Health) (all years).

Searches were conducted for all years, in all languages. For maximum sensitivity, no study design filters were applied. Given the multidisciplinary nature of this topic, databases from the fields of medicine, health, social science, and economics, and sources of grey literature (i.e., IDEAS, BLDS) were selected. The search strategy was devised for the OVID Medline interface, tested using relevant, target articles, and then adapted for the other databases. The reference lists of papers selected for full text appraisal were scanned for additional potentially relevant material.

All references were imported into an EndNote Library and tagged with the name of the database. Duplicates were removed manually within EndNote, leaving a final total of 353 results (333 from the electronic databases and 20 through the grey literature and hand searching). The reporting of the search and selection results adhered to PRISMA guidelines (Preferred Reporting Items for Systematic Reviews and Meta-Analyses) [42]. Complete search strategies for all sources are available in Additional file 1.

The literature review was designed to identify any studies on sex work in Uganda. Sex work terms included: "sex work" or "sex workers" or prostitut" or brothel" or escort or "sex adj3 buy" or "commercial adj3 sex" or "sex adj3 industry." Search terms to restrict articles to Uganda included: Uganda or Kampala or Kira or Mbarara or Mukono or Gulu or Nansana or Masaka or Kasese or Hoima or Lira or Mbale or Masindi or Njeru or Jinja or Entebbe or Arua or Wakiso or Busia or Iganga or Mpondwe or Kabale or Soroti or Mityana or Mubende.

\section{Inclusion/exclusion criteria}

Two reviewers screened all full-text articles included in the search. Any discrepancies were resolved through discussion until consensus was reached. All studies that included sex workers as the primary research participants were included in the review. Sex work was defined as exchanging sex for money or other resources as a commercial activity. Sex workers could be self-identified as female, male or transgendered. The review was not restricted to any specific content area; however, only 
studies with quantitative methodology were included in the final review.

While both sex work and transactional sex are considered forms of economically motivated sex, commercial sex workers are considered a distinct key-affected population within the HIV epidemic and specific methodologies and standard questions have been developed to record their experiences. As a result studies that focused solely on transactional sex were excluded from the review. Transactional sex was defined as non-commercial or informal exchange of sex for resources. Studies where third-party participants reported on interactions with sex workers (e.g., military, truck drivers, community members, health service providers, etc.) were not included. This search was then restricted to research studies conducted in the country of Uganda.

\section{Data extraction and synthesis}

The following data was extracted from the studies: source, setting, objective, design, sample size and characteristics, results including prevalence rates, and risk factors for various outcomes.

\section{Results}

Figure 1 provides the outlay for the study selection process. A total of 484 articles were retrieved from the database search; 20 were identified through the grey literature and hand searching. After removal of duplicates, a total of 353 articles were screened for eligibility based on title and abstract and 64 full-text articles were assessed.

The final review included 24 studies with quantitative methodology conducted among sex workers in Uganda (Table 1). The included studies were published between 1997 and 2015. There were 21 quantitative studies and three mixed method studies from eight original data sources. There were six studies from multi-national research collaborations. Three studies were conducted as part of a randomized controlled trial (RCT) investigating the clinical effectiveness of a vaginal microbicide gel to prevent HIV infection, ${ }^{1}$ with study sites in Uganda, South Africa, Benin, and India [8, 43, 44]. This trial was halted prematurely because there were higher rates of HIV acquisition among sex workers assigned to the intervention arm.

Two studies were conducted among sex workers working along the Mombassa-Kampala corridor [45, 46]. The study collected information from 1007 bars at 47 truck stops, 8 truck stop sites were in Uganda, and 39 sites were in Kenya.

A total of 18 studies from 5 data sources were conducted solely within Uganda: 12 studies included sex workers from Kampala [8, 47-57]. Three studies were conducted among sex workers in trading towns near

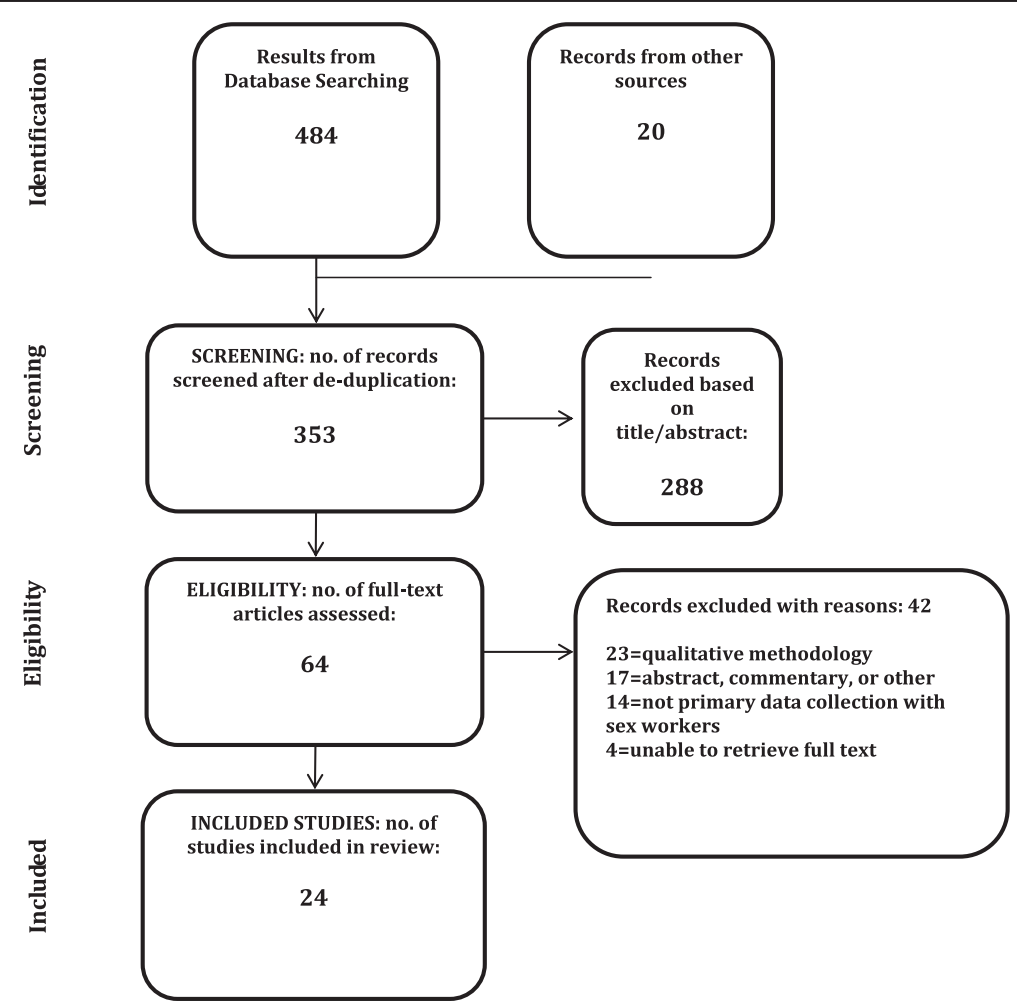

Fig 1 PRISMA flow chart: Study selection for systematic review of sex work in Uganda 
Table 1 Overview and characteristics of included studies

Source Setting Design

Objective

Sample size and

Results

Bukenya et al.

2013

Kampala

Erickson et al

2015

Francis et al.,

2013

Multisite - Uganda

(Kampala), Tanzania

Multisite: Uganda

Kampala), South Africa,

Benin, India

2012

Guédou et al 2013

Multisite: Uganda

(Kampala), South Africa,

Benin, India

Double blind RCT:

ongitudinal secondary

analysis

ongitudinal cohort:

cross-sectional analysis

To describe intervaginal

cleansing among sex

workers

Double blind RCT:

cross-sectional second-

ary analysis

To examine the association

between prevalent

intermediate vaginal flor

(IVF), bacterial vaginosis

(BV) and HIV infection

among all sex workers

screened for the RC

To examine predictors of recurrent BV

\section{$N=905$ sexually active}

Ugandan female sex

workers workers, $n=100$ Ugandan

female sex workers
$N=1367$ female sex workers, $n=516$ Ugandan female sex workers

$N=440$ female sex workers with $>1$ episode of $B V, n=167$ from Uganda

$N=259$ Ugandan female sex workers
$40.2 \%$ inconsistent condom use with paying clients in the last month. Increased

risk: sex work not the sole source of income,

sexual debut before 14 years, daily

consumption of alcohol, fewer paying

clients in last month, and currently

clients in last month, and currently married,

higher number of sexual partners.

$45.0 \%$ had ever used dual contraceptives.

Increased odds of dual contraceptive use: older age, prior unintended pregnancy, HIV testing. Decreased odds of dual

contraceptive use: rushing client

contraceptive use: rushing client

Among Ugandan sex workers: $81.8 \%$

consistent condom use in past 3 months;

$52.0 \%$ HIV positive.

Among Ugandan sex workers $100 \%$

reported intravaginal cleansing ever; 4.5

cleansing acts per day; $80.3 \%$ participants reported cleansing after half of their total sex acts. The frequency of cleansing was significant higher following sex, menstruation or vaginal discomfort.

Among total sample, $27.0 \%$ HIV prevalence, $47.6 \%$ BV prevalence, and $19.2 \%$ IVF. BV and IVF were significantly associated with HIV.

Among Ugandan sex workers, HIV prevalence $32.4 \%$, additional stratified analyses not available.

Among total sample, BV incident rate of 20.8 recurrences/100-person-months; Risk factors: vaginal cleansing increased risk; consistent condom use and vaginal candidiasis decreased risk.

Among Ugandan sex workers, 7.9 recurrences/100 person-months. No additional stratified analyses available.

$55.1 \%$ used condoms inconsistently in past month; $77.2 \%$ self-reported STI in past 12 months; $86 \%$ sought treatment 3 days after recognition of symptoms; consistent condom use was $72.1 \%$ with causal

\begin{tabular}{|c|c|c|c|}
\hline $\begin{array}{l}\text { Matovu et al., } \\
2012\end{array}$ & Kampala & Cross-sectional survey & $\begin{array}{l}\text { To assess sexual risk } \\
\text { behaviours, condom use } \\
\text { and STI infection among } \\
\text { sex workers }\end{array}$ \\
\hline
\end{tabular}


Table 1 Overview and characteristics of included studies (Continued)

$\begin{array}{llll}\begin{array}{l}\text { Morris et al., } \\ 2006\end{array} & \begin{array}{l}\text { Multisite - Uganda/ } \\ \text { Kenya on the Mobassa- } \\ \text { Kampala highway }\end{array} & \begin{array}{l}\text { Longitudinal study: } \\ \text { diaries of sexual activity } \\ \text { for } 30 \text { days }\end{array} & \begin{array}{l}\text { To exploring the effect of } \\ \text { condom use among sex } \\ \text { worker on the trans-Africa } \\ \text { highway in contributing to } \\ \text { HIV epidemic }\end{array} \\ \begin{array}{ll}\text { Morris et al., } \\ 2009\end{array} & \begin{array}{l}\text { Multisite - Uganda/ } \\ \text { Kenya on the Mobassa- } \\ \text { Kampala highway }\end{array} & \begin{array}{l}\text { Longitudinal study: } \\ \text { diaries of sexual activity } \\ \text { for } 30 \text { days }\end{array} & \begin{array}{l}\text { To describe sexual } \\ \text { behaviour among sex } \\ \text { workers on the Mombasa- } \\ \text { Kampala highway, compare } \\ \text { risk between Ugandan and } \\ \text { Kenyan sex workers }\end{array}\end{array}$

Muldoon et al.., 2014

Muldoon et al. 2015 1997a

Pickering et al., $1997 b$

Pickering et al., $1997 \mathrm{c}$
Gulu, northern Uganda

To examine the proportion of sex workers with a history of LRA abduction access to post-abduction reintegration services and relative mental health

To describe the prevalence and correlates of client

violence, assess

relationship between

policing and client

violence

Longitudinal study:

diaries of sexual activity

for 6 months

western Ugand

Trading town in southwestern Uganda

Trading town and

fishing village in southwestern Uganda

To describe sexual mixing patterns inside and outside town

To describe sexual mixing patterns

Longitudinal study: for 6 months

Longitudinal study:

diaries of sexual activity for 6 months

To describe sexual mixing patterns
$N=578$ Ugandan/Kenyan female sex workers, $n=$

175 Ugandan

$N=578$ Ugandan/Kenyan female sex workers, $n=$

175 Ugandan

$N=400$ Ugandan female sex workers, $n=129$ with history of abduction

$N=400$ Uandan female sex workers diaries of sexual activity

$N=26$ Ugandan female sex workers

$N=48$ Ugandan female sex workers

$N=81$ Ugandan female partners, $40.8 \%$ with regular partners, $6.3 \%$ with spouses.

Total of 14072 sex acts, $77.7 \%$ of sex acts used condoms; Modelling - using HIV

prevalence of $30.0-50.0 \%$ it was estimated there are 3200-4148 new HIV infections per year on the Mombasa-Kampala highway.

Compared to Ugandan sex workers, Kenyan sex workers had higher consistent condom use $(79.2 \%$ vs $73.9 \%)$, more likely to use condom during sex act, higher condom use with regular clients.

Compared to Ugandan bars, bars in Kenya were more likely to: have condom

dispensers, (25.0\% vs $1.0 \%$ ); distribute or sell condoms, (73.9\% vs $47.6 \%)$; and have more weekly condom distribution.

From a sample of 400 sex workers, $32.3 \%$

had been abducted, $43.4 \%$ had accessed a reintegration program. Mental health status was not significantly different between those who did and did not access a reintegration program. HIV prevalence $41.1 \%$.

Most common forms of client violence: physical assault $(58.7 \%)$, rape $(38.3 \%)$, gang rape (15.8\%). HIV prevalence was $33.8 \%$. inconsistent condom use was $84.0 \%$

Increased odds of client violence: rushing client negotiations because of police presence, servicing clients in a bar, inconsistent condom use with any client, working for a manager/pimp.

Women contributed 421 women-weeks; 15 were married and $42.0 \%$ of sex partner were with commercial partner; 11 were single and $20.0 \%$ of sex acts were with non-commercial partners; $90.0 \%$ of contacts were from men resident in the village.

Women contributed 789 women-weeks: average 5.8 clients per week; $10.0 \%$ of clients were non-commercial; condom use was $99.0 \%$ with commercial partners.

Women contributed 1280 women-weeks; 34 women from fishing villages and rural areas $90.0 \%$ of sex acts with local men; 47 women from town contacts $87.0 \%$ of sex 
Table 1 Overview and characteristics of included studies (Continued)

$\begin{array}{lll}\begin{array}{l}\text { Ssemwanga et al., } \\ 2012 a\end{array} & \text { Kampala } & \begin{array}{l}\text { Longitudinal cohort: } \\ \text { longitudinal clinical } \\ \text { analysis }\end{array} \\ \begin{array}{l}\text { Ssemwanga et al., } \\ 2012 b\end{array} & \text { Kampala } & \begin{array}{l}\text { Longitudinal cohort: } \\ \text { longitudinal clinical } \\ \text { analysis }\end{array} \\ \begin{array}{l}\text { Van Damme et al., } \\ 2008\end{array} & \begin{array}{l}\text { Multisite: Uganda } \\ \text { (Kampala), South Africa, } \\ \text { Benin, India }\end{array} & \begin{array}{l}\text { Double blind RCT: } \\ \text { primary analysis }\end{array}\end{array}$

Schwitters et al., Kampala $\quad$ Cross-sectional survey
2015 Benin, India

Vandepitte et al., Kampala

2011

Vandepitte et al., Kampala

$2012 \mathrm{a}$
Longitudinal cohort: cross-sectional baseline analysis
Longitudinal cohort:

longitudinal clinical

analysis
To determine the rates of HIV primary and superinfection among sex workers in Kampala

To estimate the prevalence of client initiated violence in the previous 6 months among sex workers

To identify prevalence of multiple HIV infections and associated features of partnership histories

To classify HIV drug resistance among ART naive women with new HIV diagnosis

To investigate efficacy of cellulose sulphate microbicide gel to reduce new HIV infection

To examine baseline prevalence and risk factors of HIV and STIs
$N=324$ HIV-positive Ugandan female sex workers

$N=42$ ART naïve Ugandan female sex workers with new HIV diagnosis

$N=1398$ HIV-negative female sex workers total; $N=303$ Ugandan

$N=1027$ Ugandan female sex workers

$N=1025$ endocervical swabs from Ugandan female sex workers partners were with with truck drivers or outside clients; $52.0 \%$ were HIV positive, no significant difference by location.

The prevalence of HIV superinfection was $8.2 \%$ (3.4/100 person-years) and was not significantly different from the rate of primary infection in the same population $(3.7 / 100$ person-years).

$81.8 \%$ had experienced at least one form of client-initiated violence in previous 6 months: $39.1 \%$ physical abuse, $44.7 \%$ verbal abuse, $49.1 \%$ forced sex, $54.9 \%$ not paid.

Increased odds of violence: longer duration in sex work, more frequent client demand for unprotected sex, consumption of 5+ alcoholic drink, soliciting in outdoor spaces (e.g. streets, parks, parking lots etc.).

$9.0 \%$ had multiple infections, sex workers working in same localities had phylogenetically similar viruses.

HIV drug resistance point prevalence estimate of $2.6 \%$ (95\% confidence interval, $0.1 \%-13.8 \%$ ).

Cellulose sulphate gel did not prevent HIV infection and may have increased the risk of HIV acquisition, hazard ratio 1.61 (0.9-3.0). Within Ugandan sub-group, sex workers reported 17-19 (med) sex partners, 19-21 (med) sex acts in previous 7 days $97.5 \%$ condom use per sex act. Additional stratified analyses not available.

HIV prevalence $37.0 \%$, gonorrhoea $13.0 \%$ chlamydia $8.9 \%$, T. Vaginalis $17.1 \%$, BV $55.0 \%$, candida infection $11 \%$, HSV-2 antibodies $79.9 \%$, active syphilis $10.0 \%$. Increased HIV risk: older age, widowed, lack of education, sex work as sole income, street-based sex work, not knowing HIV street-based sex work, not knowing
status, using alcohol and intravaginal status, using alcohol
cleansing with soap.

MG prevalence: $14.0 \%$ - more prevalent in HIVt; less prevalent in older women, those who were pregnant but never gave birth. who were pregnant but never gave birth.
Associated with gonorrhoeae, candida, trichomonas vaginalis. cross-sectional baseline analysis and determinants of

mycoplasma genitalium
(MG) among sex workers 
Table 1 Overview and characteristics of included studies (Continued)

\begin{tabular}{|c|c|c|c|c|c|}
\hline $\begin{array}{l}\text { Vandepitte et al., } \\
2012 \mathrm{~b}\end{array}$ & Kampala & $\begin{array}{l}\text { Longitudinal cohort: } \\
\text { cross-sectional baseline } \\
\text { clinical analysis }\end{array}$ & $\begin{array}{l}\text { To describe the symptoms } \\
\text { and signs associated with } \\
\text { MG among Ugandan sex } \\
\text { workers }\end{array}$ & $\begin{array}{l}N=1027 \text { Ugandan female } \\
\text { sex workers }\end{array}$ & $\begin{array}{l}\text { MG prevalence } 14.0 \% \text {, increased risk: } \\
\text { dysuria and mucopurulent vaginal } \\
\text { discharge. }\end{array}$ \\
\hline $\begin{array}{l}\text { Vandepitte et al., } \\
2013\end{array}$ & Kampala & $\begin{array}{l}\text { Longitudinal cohort: } \\
\text { longitudinal clinical } \\
\text { analysis }\end{array}$ & $\begin{array}{l}\text { To investigating the } \\
\text { patterns of clearance and } \\
\text { recurrence of untreated } \\
\text { MG }\end{array}$ & $\begin{array}{l}N=119 \text { Ugandan female } \\
\text { sex workers with MG }\end{array}$ & $\begin{array}{l}\text { Overall clearance rate } 25.7 / 100 \text { person years; } \\
55.0 \% \text { spontaneously cleared infection } \\
\text { within } 3 \text { months, } 83.0 \% \text { within } 6 \text { months, } \\
93.0 \% \text { within } 12 \text { months. Infection recurred } \\
\text { in } 39.0 \% \text { of women. }\end{array}$ \\
\hline $\begin{array}{l}\text { Vandepitte et al., } \\
2014 a\end{array}$ & Kampala & $\begin{array}{l}\text { Longitudinal cohort: } \\
\text { nested case control }\end{array}$ & $\begin{array}{l}\text { To examining the } \\
\text { temporal association } \\
\text { between MG status prior } \\
\text { to HIV infection }\end{array}$ & $\begin{array}{l}N=168 \text { Ugandan female } \\
\text { sex workers, } n=42 \text { cases, } \\
n=126 \text { controls }\end{array}$ & $\begin{array}{l}42 \text { sex workers acquired HIV during the } \\
\text { study, incident rate of } 3.6 / 100 \text { person years; } \\
\text { Non-significant association between MG } \\
\text { infection and HIV acquisition. }\end{array}$ \\
\hline $\begin{array}{l}\text { Vandepitte et al., } \\
2014 \mathrm{~b}\end{array}$ & Kampala & $\begin{array}{l}\text { Longitudinal cohort: } \\
\text { longitudinal clinical } \\
\text { analysis }\end{array}$ & $\begin{array}{l}\text { To assess the prevalence } \\
\text { and antimicrobial } \\
\text { susceptibility patterns of } \\
\text { gonorrhoea among sex } \\
\text { workers in Kampala }\end{array}$ & $\begin{array}{l}N=148 \text { Ugandan female } \\
\text { sex workers with diagnosis } \\
\text { of gonorrhoea }\end{array}$ & $\begin{array}{l}83.1 \% \text { ciproflaxin resistance, } 68.2 \% \\
\text { penicillin resistance. } 97.3 \% \text { tetracycline } \\
\text { resistance. }\end{array}$ \\
\hline
\end{tabular}


Lake Victoria in south-western Uganda [58-60]. Three studies were conducted among sex workers living in Gulu, northern Uganda [61-63]. All studies were among female sex workers; there were no studies with male or transgendered sex workers.

In the review process, 13 studies with qualitative methodology were identified [22-24, 28-30, 64-70]. The systematic review followed PRISMA guidelines and excluded qualitative studies and non-original research. However, the qualitative research gives critical context and voice to sex workers' narratives and lived experiences. The 13 qualitative studies were reviewed and summarized separately in Additional file 2, and key narratives related to the research are summarized in the discussion of this review.

\section{Disease burden}

Seven studies reported the HIV prevalence among Ugandan sex workers - three studies in Kampala, one study in south-western Uganda, and three in northern Uganda [43, 51, 59, 61-63, 71]. The HIV prevalence among female sex workers across the three regions ranged from $32.4 \%$ to $52.0 \%$. Independent factors significantly associated with higher odds of HIV infection included older age ( $>25$ years), being widowed, having less than primary education, sex work as sole income, street-based sex work, not knowing HIV status, using alcohol, and intravaginal cleansing with soap.

Eleven studies reported on the prevalence of STIs. The prevalence of bacterial vaginosis (BV) was between $47.6-55.0 \%[43,44,50]$. The prevalence of herpes simplex virus-2 (HSV-2) was $79.9 \%$, gonorrhoea was $13.0 \%$, trichomonas vaginalis was $17.1 \%$, candida infection was $10.9 \%$, active syphilis was $10.0 \%$, and chlamydia was $8.9 \%$ [51]. Between 8.2-9.0 \% of sex workers had multiple HIV infections [47, 48], with evidence suggesting that sex workers working in close proximity to each other had genetically similar viruses. Multidrug resistance to antiretroviral therapy was observed in $2.6 \%$ of sex workers with HIV [49] and among a sub-sample of 148 sex workers with gonorrhoea, $83.1 \%$ were resistant to ciproflaxin, $68.2 \%$ were resistant to penicillin, and $97.3 \%$ were resistant to tetracycline [52]. The prevalence of Mycoplasma genitalium (MG) infection was $14.0 \%$, and higher in HIV-positive women than in HIVnegative women [50,53]. MG clearance was shown to be slower among sex workers living with HIV and those with lower CD4 cell counts [55]. MG infection was also shown to increase the risk of HIV acquisition [54]. Among a sample of 259 sex workers in Kampala, $76.5 \%$ of sex workers self-reported an STI in the past 12 months [56].

\section{Condom use}

Ten studies reported on patterns of condom use among sex workers with recall periods ranging from the previous week to the previous six months. Inconsistent condom use within the previous month ranged from 33.3-55.1\% $[45,51,56,72]$.

In analyses of Kenyan and Ugandan sex workers along the Mombasa-Kampala corridor, a combined estimate for both Kenyan and Ugandan sex workers revealed that condoms were used in $77.7 \%$ of sex acts in the previous month [45]. Compared to Ugandan sex workers, Kenyan sex workers reported higher condom use per sex act (79.2 \% vs. $73.9 \%)$ and higher frequency of $100 \%$ condom use ( $26.8 \%$ vs. $18.9 \%$ ) [46].

Analyses within a large cohort of sex workers from Kampala (Good Health for Women Project) found that $40.2 \%$ of sex workers reported inconsistent condom use in the previous month [72]. Factors significantly associated with inconsistent condom use included sex work not being the sole source of income (AOR $=1.54 ; 95 \%$ CI: 1.13-2.09), sexual debut before 14 years $(\mathrm{AOR}=$ 1.46; 95 \% CI: 1.09-1.96), daily consumption of alcohol $(\mathrm{AOR}=1.90 ; 95 \% \mathrm{CI}: 1.26-2.88)$, and being currently pregnant $(\mathrm{AOR}=2.11 ; 95 \% \mathrm{CI}: 1.25-3.57)$. The odds of inconsistent condom use were lower among those who were currently married (AOR $=0.36$; $95 \%$ CI: 0.18-0.73) and those with more than 10 clients per month (i.e. compared to those with less than 10 clients, those with 10-19 clients (AOR: 0.65, 95 \% CI:0.44-0.96) and more than 20 clients (AOR:0.53, 95 \% CI:0.39-0.75) had lower odds) [72]. In sub-analyses of sex workers with paying clients in the previous month, only $33.9 \%$ reported consistent condom use [51], and among sex workers involved in a study that investigated intravaginal cleansing practices, $81.8 \%$ reported using condoms consistently over the past 3 months [71].

Within the microbicide randomized control trial, Ugandan sex workers reported $97.5 \%$ consistent condom use with clients in the last week [8]. A study among sex workers in Kampala found that $94.0 \%$ of sex workers had reported using a condom at least once in the previous month; however, $55.1 \%$ used condoms inconsistently. Condom use varied by partner type and was highest with casual partners (72.1 \%), regular partners $(40.8 \%)$, and spouses (6.3\%) [56].

Studies among sex workers in a trading and fishing town in south-western Uganda reported between 94.0-99.0\% used condoms with commercial partners and $59.0 \%$ of non-commercial partners in the previous six months $[58,59]$. The authors cautioned that these findings were likely subject to social desirability bias. Two studies among sex workers in northern Uganda found that 84.0-85.0 \% of sex workers 
reported inconsistent condom use with clients in the previous six months $[62,63]$.

One study included condom use as an independent variable in the regression modeling but did not include prevalence estimates, however client condom refusal (a proxy measure for inconsistent condom use) was significantly associated with increased the odds of physical, verbal, sexual violence, and economic deprivation in the previous 6 months [57].

\section{Access to health care and services}

Six studies reported on access to health care and services $[46,51,56,61-63]$. Three studies reported on access to sexual health care, including access to condoms and HIV/STI testing and treatment $[46,51,56]$. Between $62.3-97.8 \%$ of sex workers had ever tested for HIV [51, 63]. Among sex workers in Kampala, 76.5 \% (143/187) of sex workers selfreported an STI in the past 12 months and of those, $93.0 \%$ (133/143) sought treatment and of those who sought treatment, 78.2 \% (104/133) completed the treatment [56]. Between 55.0-64.4\% of sex workers report difficulty accessing condoms $[62,63]$. An analysis of the sex work environment along the Mombasa-Kampala corridor found that compared to bars in Uganda, bars in Kenya were more likely to have condom dispensers ( $25.0 \%$ vs. $1.0 \%)$, distribute or sell condoms, (73.9 \% vs. $47.6 \%$ ), and have more weekly condom distribution [46]. One analysis among sex workers with a history of abduction into the Lord's Resistance Army found that $43.4 \%$ had accessed a reintegration program for survivors of abduction [61].

Although no quantitative estimates were reported, three studies conducted in the fishing and trading towns in south-western Uganda cite that there was no health clinic or health services in the villages at the time of the research [58-60].

\section{Violence}

Three studies reported on commercial forms of violence from clients against sex workers $[57,62,63]$. In the previous 6 months, between $49.0-82.2 \%$ of sex workers had experienced at least one form of client-initiated violence [57, 62, 63], 39.1-58.7 \% had experienced physical abuse, $44.7 \%$ verbal abuse, 38.3-49.1 \% forced sex acts, and $54.9 \%$ had not been paid after sex [57, 62]. Rape from any partner in the last 6 months was $41.3 \%$. No studies reported on direct violence from police or the general public. Factors shown to significantly increase the odds of client violence were servicing clients in public spaces, inconsistent condom use with clients, working for a pimp/manager, rushing negotiation because of police presence $[57,62]$.

Two studies reported on non-commercial forms of violence against sex workers $[57,61]$. The lifetime prevalence of rape was $49.0 \%$ with the most common perpetrator from the last rape being an intimate partner $(18.2 \%)$, friend (8.2\%), authority figure (3.4\%), and family member (2.1\%). From a sample of 400 sex workers in northern Uganda, $32.3 \%$ had been forcibly abducted into the Lord's Resistance Army (LRA), considered a severe form of childhood trauma.

\section{Policing}

Two studies reported on the prevalence of policing and found $37.3 \%$ of sex workers had rushed negotiations because of police presence [62, 63], this was associated with 1.61 (95\% CI:1.03-2.52) increased odds of client violence. Between 27.8-29.6 \% of sex workers reported that police presence affected where they solicited for clients [63]. Additionally, $26.5 \%$ had been arrested [62].

\section{Discussion}

The aim of this systematic review was to summarize the epidemiological research pertaining to sex workers living and working in Uganda. There were a total of 24 studies using quantitative methodology that were conducted over the past 18 years, reporting a high prevalence of HIV and other STIs among sex workers.

The largest source of information about sex workers in Uganda is from a cohort of over 1000 sex workers in Kampala [51]. It documented a high prevalence of HIV $(37.0 \%)$, and the presence of other STIs including gonorrhoaea, syphilis, and bacterial vaginosis. Both antiretroviral drug resistance and antibiotic drug resistance were identified within this cohort. The study identified a high prevalence of inconsistent condom use in the previous month (40.2 \%). Early sexual debut and daily consumption of alcohol were statistically significantly associated with inconsistent condom use. Sub-analyses found a high prevalence of intravaginal cleansing practices [71]. This study collected information from 2008-2009, and is the main source information for several Government of Uganda national HIV reports $[21,73]$.

\section{Sex work environment}

The epidemiological research about sex workers in Uganda is largely concentrated in Kampala. Twelve of the 18 studies conducted solely in Uganda included female sex workers from Kampala. Many investigations of sex workers in sub-Saharan Africa take place in urban centres and there are likely very large populations of sex workers working in Kampala. However, extending beyond urban capitals is an important area for future research with sex workers.

Five studies were conducted along the trans-Africa highway. Three studies were conducted in trading and fishing towns in south-western Uganda, which described complex sexual mixing patterns between commercial and non-commercial partners [58-60]. There was high 
reported condom use among commercial partners and low condom use with regular and non-commercial partners. Two qualitative studies among this population were identified through the search, which also reported that consistent condom use was more difficult with regular partners [64, 65]. Fishing communities surrounding Lake Victoria have high HIV prevalence rates and are considered a key population within the national HIV strategic plan in Uganda [21]. The role of sex work within fishing communities is an important area for ongoing investigation [74].

HIV research along trucking routes has been an important source of information regarding mobile populations and spread of HIV [75-79]. This review identified two studies conducted along the Mombasa-Kampala corridor [45, 46]. Within these studies, Kenyan and Ugandan sex workers reported a relatively high proportion of condom use ( $77.7 \%$ of sex acts used condoms); however, mathematical modeling estimated that this level of inconsistent condom use could still contribute to 3200-4148 new HIV infections per year [45]. Due to high mobility, there are many challenges associated with HIV service provision for truck drivers and sex workers. One analysis that compared the sex work venues in Kenya to those in Uganda, found that the bars and lodges in Kenya were more likely to have condom dispensers, sell condoms, and have more weekly condom distributions [46]. Workplace based interventions that include condom distribution and peer-outreach at the venues along truck stops could be an important strategy for risk reduction and one that aligns with current recommendations for interventions that are grounded in community empowerment [31].

There were three analyses among sex workers from northern Uganda [61-63]. As northern Uganda has been heavily affected by war, it is a vulnerable environment where sex workers are likely working but are difficult to access. There have been some studies investigating the informal practice of transactional sex $[66,80,81]$ and sex trafficking/slavery within the LRA [82-84]. These studies showcased a high volume of violence from clients, low access to reproductive health care, high prevalence of inconsistent condom use, and a high prevalence of severe war trauma.

\section{Commercial and non-commercial violence against sex workers}

There were four studies documenting violence against sex workers in Uganda [57, 61-63]. One study among sex workers in Kampala found high levels of commercial violence from clients $(<80 \%)$ and non-commercial violence from intimate partners (18.2\%), friends (8.2\%), authority figures $(3.4 \%)$, and family members $(2.1 \%)$ [57]. Studies from northern Uganda reported that $49.0 \%$ of sex workers had experienced client violence in the previous 6 months and the most common forms were physical assault (58.7 \%), rape (38.3\%), gang rape $(15.8 \%) \quad[62,63]$. A significant source of noncommercial violence was childhood trauma, where one study reported that $32.3 \%$ of sex workers in northern Uganda had experienced extreme childhood trauma including a history of abduction into LRA [61].

Qualitative studies among sex workers in Uganda consistently documented that a serious threat to health and safety among sex workers was violence from clients, including physical and sexual assault, rape and gang rape [23, 24, 28, 29, 69]. In addition to being a serious human rights abuse, violence and fear of violence from clients is associated with increased risk of HIV infection and reduced condom use $[85,86]$. The limited availability of epidemiological information on violence against sex workers and violence within the non-commercial aspects of their lives is an area that requires further investigation in Uganda. The integration of violence prevention into comprehensive HIV programming has been shown to be an effective and important strategy, both to reduce risk of HIV and to improve general health and safety for sex workers [10, 27, 31].

Two studies reported on the prevalence or experience of policing [62, 63], including police harassment, abuse, arrest, or displacement because of police presence. Policing was directly associated with increased odds of client violence. Additionally, $26.5 \%$ had been arrested [62].

Documentation of the role of policing is an important measure for the consequences of the criminalization of sex work. This is particularly important in Uganda as the criminalization of the sex industry increases. Qualitative studies among sex workers in Uganda have documented the common occurrence of police harassment, including arbitrary arrest, degrading treatment, and physical and sexual violence [22-25, 30,69]. Given the global consensus that the criminalization of sex work is one of the largest structural determinants increasing the risk of HIV among sex workers [87], ongoing documentation of the effects of policing and criminalization of sex work is needed. International policy bodies have specifically called for the removal of all criminal laws targeting sex work as necessary for both HIV prevention and the protection of human rights $[26,76,88]$.

\section{Limitations}

The limitations of this review must be acknowledged. First, as this review was designed to assess and synthesize research with quantitative results among sex workers in Uganda, qualitative studies were not included. Qualitative studies are a necessary component of understanding the contextual and region-specific 
challenges that sex workers face and are essential to design epidemiological studies that can quantify risks and factors that impede HIV prevention. In the review process, 13 studies with qualitative methodology were identified and a summary of the results has been included in Additional file 2 and the results are discussed within this manuscript. Second, it is likely that the included studies have limited generalizability to sex workers from other settings. The scope of the review was geographically restricted to Uganda with the goal to offer a complete synthesis of all quantitative studies in Uganda independent of the topic of the study. An important gap identified in this review is the lack of regional distribution; as a result, these studies primarily summarize research from Kampala and along the transAfrica highway and are not generalizable to other regions of Uganda. Additionally, three studies originated from a clinical trial assessing the effectiveness of vaginal microbicides and self-report measures of condom-use were very high and potentially skewed because of reporting bias. Third, this review did not formally evaluate the quality of evidence in the primary research presented and the relative weight of evidence was not conducted. This does allow for a greater range of study designs and methodologies to be included and has allowed for the inclusion of studies that cover behavioural, social, and clinical epidemiology.

\section{Conclusion}

This systematic review describes the extent of the epidemiological research on sex workers in Uganda and documents multiple risk factors that contribute to the heightened burden of HIV/STIs among sex workers including challenges with consistent condom use and access to care and services. There was limited information on socio-structural factors that affect sex workers' commercial working environments in Uganda, including the role of policing and criminalization, as well as the prevalence and factors associated with violence from clients. The majority of the existing evidence comes from sex workers in Kampala, highlighting a need for information on sex work in other regions of Uganda. Additionally, there is limited information on features of the noncommercial components of sex workers' lives as well as the services needed to reduce risks outside of the sex industry. Moving forward, evidence is needed to further inform programming that can reduce risks associated with HIV/STIs and violence. Specifically, communitybased programming designed to reach sex workers and provide support and education to reduce harms is needed. Successful models of care delivery include sex worker/peer-led outreach programs to reach sex workers who may be more hidden and less likely to access services. Best practices for programming with sex workers includes involving sex workers in all aspects of research and programming. As research continues, a combination of both clinical and social aspects of sex workers lives is needed to ensure that potential for successful programming and policy are realized.

\section{Endnotes}

${ }^{1}$ CONRAD Sulfate randomized control trial http:// www.isrctn.com/ISRCTN95638385

\section{Additional files}

Additional file 1: Search Strategies and results summary. (DOCX $40 \mathrm{~kb}$ ) Additional file 2: Overview and characteristics of 13 qualitative studies of sex workers in Uganda. (DOC $124 \mathrm{~kb}$ )

\section{Competing interests}

None to declare. There was no funding for this systematic review.

\section{Authors contributions}

KAM developed the analysis plan, extracted the data, conducted the analysis and wrote the manuscript.

\section{Acknowledgments}

I would like to thank Drs. Kate Shannon, Jean Shoveller, Edward Mills for their supervisory support. I would like to thank Bill Cameron and Tamara Rader for their technical support. KAM is funded through a doctoral fellowship from the Canadian Association for HIV/AIDS Research and is a Liu Scholar at the Liu Institute for Global Issues at the University of British Columbia.

Received: 7 July 2015 Accepted: 1 December 2015

Published online: 09 December 2015

\section{References}

1. Baral SD, Beyrer C, Muessig K, Poteat T, Wirtz AL, Decker MR, et al. Burden of HIV among female sex workers in low-income and middle-income countries: a systematic review and meta-analysis. Lancet Infect Dis. 2012;12: 538-49.

2. Berkley SF, Widy-Wirski R, Okware SI, Downing R, Linnan MJ, White KE, et al. Risk factors associated with HIV infection in Uganda. J Infect Dis. 1989;160: 22-30.

3. Hennis AJ, Kataaha P, Lloyd G, Moore AT, Sutehall GM, Whetstone R, et al. Risk factors for the spread of AIDS in rural Africa: evidence from a comparative seroepidemiological survey of AIDS, hepatitis B and syphilis in southwestern Uganda. AIDS. 1988;2:255-60.

4. Fleming AF. Seroepidemiology of human immunodeficiency viruses in Africa. Biomed Pharmacother. 1988;42:309-20.

5. Marcus R: Gender and HIV/AIDS in Subsaharan Africa: the Cases of Uganda and Malawi. Brighton: BRIDGE, Institute of Develment Studies. 1993

6. Baeten JM, Donnell D, Ndase P, Mugo NR, Campbell JD, Wangisi J, et al. Antiretroviral prophylaxis for HIV prevention in heterosexual men and women. N Engl J Med. 2012;367:399-410.

7. Siegfried N, Van Der Merwe L, Brocklehurst $P$, Sint $\Pi$ : Antiretrovirals for reducing the risk of mother-to-child transmission of HIV infection (Review). Cochrane Collab 2011;7:1-12

8. Van Damme L, Govinden R, Mirembe FM, Guédou F, Solomon S, Becker ML, et al. Lack of effectiveness of cellulose sulfate gel for the prevention of vaginal HIV transmission. N Engl J Med. 2008;359:463-72.

9. Kerrigan D, Wirtz A, Semini I, N'Jie N, Stanciole A, Butler J, Oelrichs R, Beyrer C. The global HIV epidemics among sex workers. The World Bank; 2013

10. Beyrer C, Crago AL, Bekker LG, Butler J, Shannon K, Kerrigan D, et al. An action agenda for HIV and sex workers. Lancet. 2014;6736:1-14.

11. Ngugi E, Roth E, Mastin T, Nderitu MG, Yasmin S. Female sex workers in Africa: epidemiology overview, data gaps, ways forward. J Soc Asp HIV/AIDS Res Alliance. 2012;9:148-53. 
12. Djomand $G$, Quaye $S$, Sullivan $P S$. HIV epidemic among key populations in west Africa. Curr Opin HIV AIDS. 2014;9:506-13.

13. Papworth E, Ceesay N, An L, Thiam-Niangoin M, Ky-Zerbo O, Holland C, et al. Epidemiology of HIV among female sex workers, their clients, men who have sex with men and people who inject drugs in west and central africa. J Int AIDS Soc. 2013;16 Suppl 3:1-11.

14. Shannon K, Strathdee SA, Goldenberg SM, Duff PK, Mwangi P, Rusakova M, et al. Global epidemiology of HIV among female sex workers: influence of structural determinants. Lancet. 2014;6736:1-17.

15. Scorgie F, Chersich MF, Ntaganira I, Gerbase A, Lule F, Lo Y-R. Sociodemographic characteristics and behavioral risk factors of female sex workers in sub-saharan Africa: a systematic review. AIDS Behav. 2011;16:920-33.

16. Deering KN, Amin A, Shoveller J, Nesbitt A, Garcia-Moreno C, Duff P, et al. A systematic review of the correlates of violence against sex workers. Am J Public Health. 2014;104:e42-54.

17. Ngugi $E$, Benoit $C$, Hallgrimsdottir H, Jansson M, Roth EA. Family kinship patterns and female sex work in the informal urban settlement of Kibera, Nairobi, Kenya. Hum Ecol. 2012;40:397-403.

18. Chapter 120: Penal Code Act [http://www.ulii.org/ug/legislation/ consolidated-act/120]

19. Anti-Pornography Act of 2014 [http://www.ulrc.go.ug/ulrcsite/download/ file/fid/321]

20. Anti-Pornography Bill, 2011 [https://jssozi.files.wordpress.com/2013/04/antipornography-bill-2011.pdf]

21. Government of Uganda: HIV and AIDS Uganda country progress report. 2013.

22. Mbonye M, Nalukenge W, Nakamanya S, Nalusiba B, King R, Vandepitte J, et al. Gender inequity in the lives of women involved in sex work in Kampala, Uganda. J Int AIDS Soc. 2012;15 Suppl 1:1-9.

23. Mbonye M, Nakamanya S, Nalukenge W, King R, Vandepitte J, Seeley J. "It is like a tomato stall where someone can pick what he likes": structure and practices of female sex work in Kampala, Uganda. BMC Public Health. 2013; 13:741-50.

24. Scorgie F, Nakato D, Harper E, Richter M, Maseko S, Nare P, et al. "We are despised in the hospitals": sex workers' experiences of accessing health care in four African countries. Cult Health Sex. 2013;15:450-65.

25. Mbonye M, Rutakumwa R, Weiss H, Seeley J. Alcohol consumption and high risk sexual behaviour among female sex workers in Uganda. Afr J AIDS Res. 2014:13:145-51.

26. Decker MR, Crago AL, Chu SK, Sherman SG, Seshu MS, Buthelezi K, et al. Human rights violations against sex workers: burden and effect on HIV. Lancet. 2014;6736:1-14.

27. Chersich MF, Luchters S, Ntaganira I, Gerbase A, Lo Y-RR, Scorgie F, et al. Priority interventions to reduce HIV transmission in sex work settings in subSaharan Africa and delivery of these services. J Int AIDS Soc. 2013;16:1-8,

28. Ntozi JPM, Mulindwa IN, Ahimbisibwe F, Ayiga N, Odwee J, Najjumba IM, et al. Has the HIV/AIDS epidemic changed sexual behaviour of high risk groups in Uganda? Afr Health Sci. 2003;3:107-16.

29. Schoemaker J, Twikirize J. A life of fear: sex workers and the threat of HIV in Uganda. Int J Soc Welf. 2012;21:186-93.

30. Scorgie F, Vasey K, Harper E, Richter M, Nare P, Maseko S, et al. Human rights abuses and collective resilience among sex workers in four African countries: a qualitative study. Global Health. 2013;9:33-46.

31. Moore L, Chersich MF, Steen R, Reza-Paul S, Dhana A, Vuylsteke B, et al. Community empowerment and involvement of female sex workers in targeted sexual and reproductive health interventions in Africa: a systematic review. Global Health. 2014;10:47-64.

32. Scheibe A, Drame FM, Shannon K. HIV prevention among female sex workers in Africa. J Soc Asp HIV/AIDS Res Alliance. 2012;9:167-72.

33. Baleta A. Lives on the line: sex work in sub-Saharan Africa. Lancet. 2014;6736.

34. World Health Organization: Consolidated guidelines on HIV prevention, diagnosis, treatment and care for key populations. Geneva: World Health Organization. 2014(July).

35. World Health Organization, UNFPA, UNAIDS, Global Network of Sex Work Projects: Prevention and treatment of HIV and other sexually transmitted infections for sex workers in Low- and Middle-Income Countries: Recommendations for a public health approach. 2012(December).

36. UNAIDS: UNAIDS guidance note on HIV and sex work. Geneva: UNAIDS. 2012.

37. Dhana A, Luchters S, Moore L, Lafort Y, Roy A, Scorgie F, et al. Systematic review of facility-based sexual and reproductive health services for female sex workers in Africa. Global Health. 2014;10:46-75.
38. Chersich MF, Luchters S, Ntaganira I, Gerbase A, Lo Y-R, Scorgie F, et al, Priority interventions to reduce HIV transmission in sex work settings in subSaharan Africa and delivery of these services. J Int AIDS Soc. 2013;16:17980

39. Shahmanesh M, Patel V, Mabey DC, Cowan FM. Effectiveness of interventions for the prevention of HIV and other sexually transmitted infections in female sex workers in resource poor setting: a systematic review. Trop Med Int Heal. 2008;13:659-79.

40. PROSPERO: International prospective register of systematic reviews [http:// www.crd.york.ac.uk/PROSPERO/]

41. Higgins J, Churchill R, Lasserson T, Chandler J, Tovey D: Methodological Standards for the Conduct of New Cochrane Intervention Reviews (MERCIR). 2013(December).

42. Moher D, Liberati A, Tetzlaff J, Altman DG. Academia and clinic annals of internal medicine preferred reporting items for systematic reviews and meta-analyses. Annu Intern Med. 2009;151:264-9.

43. Guédou FA, Van Damme L, Deese J, Crucitti T, Becker M, Mirembe F, et al. Behavioural and medical predictors of bacterial vaginosis recurrence among female sex workers: longitudinal analysis from a randomized controlled trial. BMC Infect Dis. 2013:13:208-19.

44. Guédou FA, Van Damme L, Mirembe F, Solomon S, Becker M, Deese J, et al. Intermediate vaginal flora is associated with HIV prevalence as strongly as bacterial vaginosis in a cross-sectional study of participants screened for a randomised controlled trial. Sex Transm Infect. 2012:88:545-51.

45. Morris CN, Ferguson AG. Estimation of the sexual transmission of HIV in Kenya and Uganda on the trans-Africa highway: The continuing role for prevention in high risk groups. Sex Transm Infect. 2006;82:368-71.

46. Morris CN, Morris SR, Ferguson AG. Sexual behavior of female sex workers and access to condoms in Kenya and Uganda on the Trans-Africa highway. AIDS Behav. 2009:13:860-5.

47. Redd AD, Ssemwanga D, Vandepitte J, Wendel SK, Ndembi N, Bukenya J, et al. Rates of HIV-1 superinfection and primary HIV-1 infection are similar in female sex workers in Uganda. AIDS. 2014;28:2147-52.

48. Ssemwanga D, Ndembi N, Lyagoba F, Bukenya J, Seeley J, Vandepitte J, et al. HIV Type 1 subtype distribution, multiple infections, sexual networks, and partnership histories in female sex workers in Kampala, Uganda. AIDS Res Hum Retroviruses. 2012;28:357-65.

49. Ssemwanga D, Ndembi N, Lyagoba F, Magambo B, Kapaata A, Bukenya J, et al. Transmitted antiretroviral drug resistance among drug-naive female sex workers with recent infection in Kampala, Uganda. Clin Infect Dis. 2012; 54:S339-42.

50. Vandepitte JM, Bukenya J, Hughes P, Muller E, Buvé A, Hayes R, et al. Clinical characteristics associated with Mycoplasma genitalium infection among women at high risk of HIV and other STI in Uganda. Sex Transm Dis. 2012; 39:487-91.

51. Vandepitte JM, Bukenya J, Weiss HA, Nakubulwa S, Francis SC, Hughes P, et al. HIV and other sexually transmitted infections in a cohort of women involved in high risk sexual behaviour in Kampala, Uganda. Sex Transm Dis. 2011;38:316-23.

52. Vandepitte JM, Hughes P, Matovu G, Bukenya J, Grosskurth H, Lewis DA. High prevalence of ciprofloxacin-resistant gonorrhea among female sex workers in Kampala, Uganda (2008-2009). Sex Transm Dis. 2014;41:233-7.

53. Vandepitte JM, Muller E, Bukenya J, Nakubulwa S, Kyakuwa N, Buve A, et al. Prevalence and correlates of Mycoplasma genitalium infection among female sex workers in Kampala, Uganda. J Infect Dis. 2012;205:289-96.

54. Vandepitte JM, Weiss HA, Bukenya J, Kyakuwa N, Muller E, Buve A, et al. Association between Mycoplasma genitalium infection and HIV acquisition among female sex workers in Uganda: evidence from a nested case-control study. Sex Transm Infect. 2014;90:545-9.

55. Vandepitte JM, Weiss HA, Kyakuwa N, Nakubulwa S, Muller E, Buve A, et al. Natural history of Mycoplasma genitalium infection in a cohort of female sex workers in Kampala, Uganda. Sex Transm Dis. 2013;40:422-7.

56. Matovu J, Ssebadduka B. Sexual risk behaviours, condom use and sexually transmitted infection treatment-seeking behaviours among female sex workers and truck drivers in Uganda. Int J STD AIDS. 2012;23:267-73.

57. Schwitters A, Swaminathan M, Serwadda D, Muyonga M, Shiraishi RW, Benech I, et al. Prevalence of rape and client-initiated gender-based violence among female sex workers: Kampala, Uganda, 2012. AIDS Behav 2015:19:68-76.

58. Pickering H, Okongo M, Nnalusiba B, Bwanika K, Whitworth J. Sexual networks in Uganda: casual and commercial sex in a trading town. AIDS Care. 1997;9:199-207. 
59. Pickering $\mathrm{H}$, Okongo M, Ojwiya A, Yirrell $\mathrm{D}$, Whitworth J. Sexual networks in Uganda: mixing patterns between a trading town, its rural hinterland and a nearby fishing village. Int J STD AIDS. 1997;8:495-500.

60. Pickering $H$, Okongo M, Bwanika K, Nnalusiba B, Whitworth J. Sexual behaviour in a fishing community on Lake Victoria, Uganda. Health Transit Rev. 1997;7:13-20.

61. Muldoon KA, Muzaaya G, Betancourt TS, Ajok M, Akello M, Petruf Z, et al. After abduction: exploring access to reintegration programs and mental health status among young female abductees in northern Uganda. Confl Health. 2014:8:1-9.

62. Muldoon KA, Akello M, Muzaaya G, Simo A, Shoveller J, Shannon K: Policing the epidemic: high burden of workplace violence among female sex workers in conflict-affected northern Uganda. Glob Public Health 2015, in press.

63. Erickson M, Goldenberg SM, Ajok M, Muldoon K a., Muzaaya G, Shannon K: Structural determinants of dual contraceptive use among female sex workers in Gulu, northern Uganda. Int J Gynecol Obstet. 2015;131:91-5.

64. Gysels M, Pool R, Bwanika K. Truck drivers, middlemen and commercial sex workers: AIDS and the mediation of sex in south west Uganda. AIDS Care. 2001:13:373-85.

65. Gysels M, Pool R, Nnalusiba B. Women who sell sex in a Ugandan trading town: life histories, survival strategies and risk. Soc Sci Med. 2002;54:179-92.

66. Lees S, Zalwango F, Andrew B, Vandepitte J, Seeley J, Hayes RJ, et al. Understanding motives for intravaginal practices amongst Tanzanian and Ugandan women at high risk of HIV infection: the embodiment of social and cultural norms and well-being. Soc Sci Med. 2014;102:165-73.

67. Marlow HM, Shellenberg K, Yegon E. Abortion services for sex workers in Uganda: successful strategies in an urban clinic. Cult Health Sex. 2014;16: 931-43.

68. Mbonye M, Rutakumwa R, Weiss H, Seeley JLB-W. Alcohol consumption and high risk sexual behaviour among female sex workers in Uganda. Ajar-African J Aids Res. 2014;13:145-51.

69. Nyanzi S. Homosexuality, Sex work, and HIV/AIDS in displacement and postconflict settings: the case of refugees in Uganda. Int Peacekeeping. 2013;20: 450-68.

70. Zalwango F, Eriksson L, Seeley J, Vandepitte J, Grosskurth H: Parenting and money making: sex work and women's choices in urban Uganda. Wagadu 2010, 8:71-92

71. Francis SC, Baisley K, Lees SS, Andrew B, Zalwango F, Seeley J, et al. Vaginal practices among women at high risk of HIV infection in Uganda and Tanzania: recorded behaviour from a daily pictorial diary. PLoS One. 2013;8: e59085.

72. Bukenya J, Vandepitte J, Kwikiriza M, Weiss HA, Hayes R, Grosskurth H. Condom use among female sex workers in Uganda. AIDS Care. 2013;25:767-74.

73. Government of Uganda: UNGASS Country Progress Report: Uganda. Kampala: Government of Uganda. 2010.

74. Smolak A. A meta-analysis and systematic review of HIV risk behavior among fishermen. AIDS Care. 2013;00:1-10.

75. Delany-Moretlwe S, Bello B, Kinross P, Oliff M, Chersich M, Kleinschmidt I, et al. HIV prevalence and risk in long-distance truck drivers in South Africa: a national cross-sectional survey. Int J STD AIDS. 2014;25:428-38.

76. Beyrer C, Baral SD, Kerrigan D, El-Bassel N, Bekker L, Celentano DD. Expanding the space: inclusion of Most-at-Risk Populations in HIV prevention, treatment, and care services. J Acquir Immune Defic Syndr. 2011;57 Suppl 2:1-7.

77. Magnani R, Sabin K, Saidel T, Heckathorn D. Review of sampling hard-toreach and hidden populations for HIV surveillance. AIDS. 2005;19:67-72.

78. Coates TJ, Richter L, Caceres C. Behavioural strategies to reduce HIV transmission: how to make them work better. Lancet. 2008;372:669-84.

79. Richter M, Scorgie F, Chersich MF, Luchters S. 'There are a lot of new people in town: but they are here for soccer, not for business' a qualitative inquiry into the impact of the 2010 soccer world cup on sex work in South Africa. Global Health. 2014;10:45-56.

80. Rujumba J, Kwiringira J. Interface of culture, insecurity and HIV and AIDS: lessons from displaced communities in Pader District, northern Uganda. Confl Health. 2010;4:18-28.

81. Patel S, Schechter MT, Sewankambo NK, Atim S, Lakor S, Kiwanuka N, et al. War and HIV: sex and gender differences in risk behaviour among young men and women in post-conflict Gulu District, northern Uganda. Glob Public Health. 2014;9:325-41.

82. Mckay S. Reconstructing fragile lives: girls' social reintegration in northern Uganda and Sierra Leone. Gend Dev. 2004;12:19-30.
83. Westerhaus MJ. Linking anthropological analysis and epidemiological evidence: formulating a narrative of HIV transmission in Acholiland of northern Uganda. J Soc Asp HIV/AIDS. 2007:4:590-605.

84. Oosterhoff $P$, Mills $E$, Oosterom M: Addressing sexual violence in and beyond the 'warzone.' Rapid Response 2014;471-4

85. Decker MR, Pearson E, Illangasekare SL, Clark E, Sherman SG. Violence against women in sex work and HIV risk implications differ qualitatively by perpetrator. BMC Public Health. 2013;13:876.

86. Okal J, Chersich MF, Tsui S, Sutherland E, Temmerman M, Luchters S. Sexual and physical violence against female sex workers in Kenya: a qualitative enquiry. AIDS Care. 2011;23(March 2015):612-8.

87. World AIDS Campaign: Sex work and the law: the case for decriminalization. 2010.

88. Kerrigan D, Kennedy CE, Morgan-Thomas R, Reza-Paul S, Mwangi P, Win KT, et al. A community empowerment approach to the HIV response among sex workers: effectiveness, challenges, and considerations for implementation and scale-up. Lancet. 2014;6736:1-14.

\section{Submit your next manuscript to BioMed Central and we will help you at every step:}

- We accept pre-submission inquiries

- Our selector tool helps you to find the most relevant journal

- We provide round the clock customer support

- Convenient online submission

- Thorough peer review

- Inclusion in PubMed and all major indexing services

- Maximum visibility for your research

Submit your manuscript at www.biomedcentral.com/submit 